\title{
Patriarchy and Child Entrepreneurship in Akwa Ibom North- East Senatorial District of Akwa Ibom State, Nigeria.
}

\author{
OBINAJU, Queen Idongesit (Ph.D) ${ }^{1 *}$, EJEKWU, Princewill Okechukwu (Ph.D) ${ }^{2}$, PETER, \\ Ubong Sunday ${ }^{1}$ \\ ${ }^{I}$ Department of Early Childhood and Special Education University of Uyo, Uyo \\ ${ }^{2}$ Department of Early Childhood and Primary Education Ignatius Ajuru University of Education, Port Harcourt \\ *Corresponding Author: OBINAJU, Queen Idongesit (Ph.D), Department of Early Childhood and \\ Special Education University of Uyo, Uyo
}

\begin{abstract}
This study examined the effect of Patriarchy and Child Entrepreneurship in Akwa Ibom North-East Senatorial District of Akwa Ibom State, Nigeria. Three specific objectives, three research questions and null hypotheses guided the study. The ex-post facto survey research design was adopted for the study. The population consisted of 29,119 basic five pupils; out of which 1,455 were drawn as sample using stratified random sampling technique. The Child Entrepreneurship Scale was used for data collection. The data was analyzed using independent t-test. The findings of the study revealed that there is a significant influence of parental patriarchy on child entrepreneurship in primary schools; there is a significant influence of economic patriarchy on child entrepreneurship in primary schools; there is a significant influence of religious patriarchy on child entrepreneurship in primary schools. Recommendations were made which include that parents should endeavour to reorganize their female children's rearing patters in order to cultivate equality beliefs in them to inhibit patriarchal reasoning that would pose a serious challenge in motivating them for the development of entrepreneurship skills.
\end{abstract}

Keywords: Patriarchy, Entrepreneurship, Parental patriarchy, Economic patriarchy, religious patriarchy

\section{INTRODUCTION}

Patriarchy seems to be a global phenomenon that describes the male domination and oppression in the society. Patriarchy is perhaps, made up of societal structures or institutions that exclude women from participating economically, politically, culturally and religiously. It is a form of mental, social, spiritual, economic and political organization or structuring of society produced by the gradual institutionalization of sex-based political relations which is created, maintained and reinforced by different institutions linked closely together to achieve consensus on the lesser value of women and their roles (Tickner, 2011).

Buss, and Schmitt (2011) observed that in Nigeria, patriarchy may be seen as a social system in which males hold superior power, predominate in roles of political leadership, moral authority, social privileges and control of property in the family. It is this patriarchal right that empowers fathers or father-figure to hold authority over women and children as customarily recognized head of the family (Buss, and Schmitt, 2011). In the same vein, Ezenwa-Ohaeto (2015) acknowledged that patriarchy is a common cultural feature in Nigeria that extols males-authority, domination and supremacy over the female in all spheres of human endeavour. This implies that men hold power in all the important institutions of the society and that women are deprived of access to such power.

However, Sultana (2011) sees patriarchy is an index which the society traditionally trying to preserve the male gender to dominate and the female as subordinate. Thus, the subordination experienced daily by women regardless of the class any woman belongs to, takes various forms such as discrimination, disregard, insult, control, exploitation, oppression, violence within the family, at the place of work and in the society. Also, Tickner (2011) sees patriarchy as a form of mental, social, spiritual, economic and political organization or structuring of society produced by the gradual institutionalization of sex-based political relations created, maintained and reinforced by different institutions linked closely together to achieve consensus on the lesser value of women and their roles. 
In examining the role patriarchy play among men and women, Johnson (2005) asserts that patriarchy does not mean that all men are powerful and all women are powerless, rather it does indicate that the most powerful roles are held by men; that men are in positions of authority because of their ability to exert control through violence or threat of violence, and that personal attributes and social activities closely tied to men are more highly regarded in society. Consequently, Hooks (2010) asserted that males as a group have and do benefit the most from patriarchy, from the assumption that they are superior to females and should rule over women.

In considering parental patriarchy, it should be noted that the family, as a social institution, is a brewery for patriarchal practices by socializing the young children to accept sexually differentiated roles. Kambarami (2006) observes that in Nigeria, many cultures, from a tender age, uphold the socialization process that differentiates the girl child from the boy child. Nigerian males are socialized to view themselves as breadwinners and heads of households whilst females are taught to be obedient and submissive housekeepers. In the family, the male child is preferred to the female child. In fact, males rule females by right of birth and even if the male child is not the first born in a family, he is automatically considered the head of the household who should protect and look after his sisters (Kambarami, 2006). Similarly, Adichie (2009) states that in some cultures in Nigeria, the belief is that the girl child would eventually be married out of the family, and perhaps she is not part of the inheritance, and as such, the girl child is an inheritable estate for another family, which could be inherited by the brother-in-law or the nearest relation of the husband, whenever the husband dies.

Kambarami (2006) further observed that in some cultures, once a girl reaches puberty all teachings are directed towards pleasing one's future husband as well as being a gentle and obedient wife; to the extent that their sexuality is further defined for such purpose(s) as being taught on how to use it for the benefit of the male race. Kambarami noted further that, these cultural teachings foster a dependence syndrome which is why most African women depend heavily on their husband for support. As a result, once a husband dies, the woman may likely remarry quickly so as to find another pillar of support to lean on.

Economic patriarchy is the process by which parents expose children to different socializing patterns with respect to their gender in preparing them for the various occupational roles later in life. Oguejio for (2015) and Makama (2013) agreed that part of the result of Nigerian patriarchal practices is the antecedence of the early development of the male child through traditional occupational role playing. Effiong (2012) opined that economic patriarchy is seen as a gender-based political cultivation of occupation and means of livelihood into the characteristics of children with regards to their stable income generation in the future. Also, Udoh (2004) observed that skills development as part of entrepreneurship in most traditional industries were imparted through functionally and informal education that introduced gender disparity among trainees based on the gender role identity as perceived by industrial leaders of the community.

Patriarchal attitudes also exist in the corporate world and few women are allowed to occupy leadership positions (Kambarami, 2006). Furthermore, Kambarami added that most women occupy less challenging positions like secretarial or clerical positions and few in administrative positions. Obisong (2005) has observed that it is the male child that should acquire managerial skills and production strategies to help their father in business and inherit the business for sustenance of their father's dynasty during the father's old age or death. Ebom (2015) posits that patriarchal culture of the people has adverse effects on the amount of business capital and economic standpoint that male and female entrepreneurs can attract. Similarly, Tuned (2011) noted that more male children are trained in managing beer shops, wine shop, hotels, engineering factory, while the female children are trained to manage kitchens, eating houses, fast food shops, and snack shop as well as men's emotions.

Religious patriarchy emanates from the knowledge of creation, which revealed that a woman was made from the rib of a man and that the woman was identified as a helpmate. This understanding seems to play a role on patriarchal beliefs and internalizes such behaviours as a socially recognized roles. According to Silversetin, Auerbach and Dunkel (2009), men's roles are not patriarchal but one of spiritual leaders and that their position as leaders are both religiously and biological sanctioned. The authors reiterated that, by redefining the father as spiritual leader, rather than patriarch, the father maintains power and status. 
Bula (2012) acknowledge entrepreneurship as the act of being an entrepreneur, which can be defined as one who undertakes innovations, finances and displays business acumen in an effort to transform innovations into economic goods. This may result in new organizations or may be part of revitalizing mature organizations in response to a perceived opportunity. In his contribution, Effiong (2015) states that entrepreneurship is the ability of an individual to be an entrepreneur that is driven by the need to attain a specific goal, to experiment, exhibit creativity and, accomplish a venture through commensurate risk-taking.

As noted by Oteh (2009), the child nurtured with entrepreneurial ability is capable of enjoying independent living and may be free from patriarchy as a form of dominance in all ramifications. This capability would sustain the individual child whether male or female. Entrepreneurship seems to be the concrete avenue to escape dominance, discrimination and subjugation that tend to reduce women to subordinates.

The whole idea about entrepreneurship is about self-employment which will generate employment opportunities to others that must work with entrepreneur. Baba (2013) asserted that entrepreneurship is the most effective method for bridging the gap between science and the market place, creating new enterprises, and bringing new products and service to the market. These entrepreneurial activities significantly affect the economy of an area by building their economic base and providing jobs. Praag and Versloot (2007) belief that entrepreneurship will help in combating unemployment, poverty, under-development and will also engender economic development. It is postulated that patriarchal experiences of women may take many forms, which include parental patriarchy, religious patriarchy, heterosexual patriarchy, economic patriarchy and educational patriarchy.

As observed by Emmanuel (2008), an individual's environment is the major motivating factor for entrepreneurship; ideas, traits and motives are not enough on their own for entrepreneurship to manifest. In corroborating this view, Thornton (2009) makes a distinction between the role of individuals with identifiable entrepreneurial traits and characteristics, classified as supply-side perspective and the role of culture and environment (demand perspective) in the development of entrepreneurial skills. It is believed that individuals, organizations and cultural structure may be influenced by their social context. Patriarchy, in this vein, seem to be a social norm created for men to dominate, subjugate and exclude women from taking equal participations in the general human activities in life. Accordingly, this norm and practices position women as inferior to men; men impose control on-them, which may be present in families, social relationships, religious settings, schools, cooperate organizations and public offices. Inadvertently, this situation make most women feel weak and powerless, even though they are not. Thus, the feeling of powerlessness, discrimination and experience of limited self-esteem and self-confidence may negatively influence their entrepreneurship.

\section{Statement of The Problem}

It is certain that gender discrimination exist in the distribution of wealth and economic empowerment of children in Akwa Ibom North-East Senatorial District. This is because the patriarchal social and cultural practices favour the allocation of family estates including economic factors, and entrepreneurship right to male children. Patriarchal system impoverishes women and girl children in Akwa Ibom North-East Senatorial District. At the moment, there is leanness of data on the effect of efforts made so far by some women, men and some concerned organizations to reduce or control the impact of patriarchy on the economic empowerment and development of entrepreneurial skills among children in the study area. The problem of this study concentrates on how patriarchy affects the development of entrepreneurial skills among children in Akwa Ibom North-East Senatorial District of Akwa Ibom State. This study investigates the influence of patriarchy on child entrepreneurship in Akwa Ibom North-East Senatorial District of Akwa Ibom State.

\subsection{Purpose of the Study}

This study aimed at determining the influence of patriarchy on child entrepreneurship in Akwa Ibom North-East Senatorial District of Akwa Ibom State, Nigeria. Specifically, the study sought to:

1. Determine the influence of parental patriarchy on child entrepreneurship in Akwa Ibom NorthEast Senatorial District of Akwa Ibom State. 
2. Determine the influence of economic patriarchy on child entrepreneurship in Akwa Ibom NorthEast Senatorial District of Akwa Ibom State.

3. Ascertain the influence of religious patriarchy on child entrepreneurship in Akwa Ibom NorthEast Senatorial District of Akwa Ibom State.

\subsection{Null Hypotheses}

The following null hypotheses were formulated based on the research questions and tested at .05 level of significance:

1. There is no significant influence of parental patriarchy on child entrepreneurship in Akwa Ibom North-East Senatorial District of Akwa Ibom State.

2. There is no significant influence of economic patriarchy on child entrepreneurship in Akwa Ibom North-East Senatorial District of Akwa Ibom State.

3. There is no significant influence of religious patriarchy on child entrepreneurship in Akwa Ibom North-East Senatorial District of Akwa Ibom State.

\section{Methodology}

\subsection{Research Design}

The ex-post facto survey research design was used for the study. The choice of the research design was based on the fact that the variables under study have already occurred or existed without the direct manipulation by the researcher. Akuezuilo and Agu (2003) explained that in ex-post facto survey design, the relations among variables are made without direct manipulations of the variables because the variable characteristics had already existed and they are inherently not controllable.

\subsection{Population for the Study}

29,119 basic five pupils in the 384 Public primary schools in Akwa Ibom North-East Senatorial District comprised the population of the study (Akwa Ibom State Universal Basic Education Board, 2017).

\subsection{Sample and Sampling Techniques}

1,455 basic five pupils representing $5 \%$ of the study's population were sampled for the study. The stratified random sampling was used to draw the respondents from the nine local government areas in the Senatorial District. The population was divided into nine strata; each stratum representing a local government area, thereafter, simple random sampling procedure was used to draw the sampled schools. A total of 19 public primary schools were sampled which represent $5 \%$ of the school population for the study. However, on arrival at the sampled schools, intact classes of basic five were used as sample for this study.

\subsection{Instrument for Data Collection}

A researcher - made instrument titled "Patriarchy in Child Entrepreneurship Scale (PCES)" was used for data collection. The instrument had sections A and B. Section A had 30 items which sought information on patriarchal variables responded by the pupils. While section B had 10 items statement that elicited information on child entrepreneurship. Both sections therefore had a total of 40 items measure that matched the sub-constructs of independent variable with dependent variable respectively, in this study. The instrument had a four point summated scale with the weights of 4 to 1 representing: Strongly Agree $(\mathrm{SA}=4)$, Agree $(\mathrm{A}=3)$, Disagree $=2$ and Strongly Disagree $(\mathrm{SD})=1$. Items of the questionnaires were generally positive and negative, where the negative items took the reverse of the scale, as Strongly Agree $(\mathrm{SA}=1)$ to Strongly Disagree $(\mathrm{SD}=4)$.

\subsection{Validation of the Instrument}

Face validity was used to validate the instrument. The instrument was validated by 2 experts in Early Childhood Education, 2 experts in Business Education and 1 expert in Test and Measurement, all in Faculty of Education, University of Uyo, Uyo. They read and corrected ambiguities' in the items of the instrument to be sure that the variables were well represented. The researcher's supervisor guided the researcher in effecting major corrections and selection 


\subsection{Reliability of the Instrument}

The internal consistency approach was adopted for this study. The pilot test was conducted on 30 public primary school pupils in Uyo Local Government Area of Akwa Ibom State to determine the reliability indices of this study. The primary school pupils used for the pilot test were not part of the population, but believed to have shared similar characteristics with that of the individuals used in this study. However, the scores collected from the validated instrument were used to compute the reliability using Cronbach Alpha Statistics that yielded the reliability indices (parental Patriarchy $=$ .84 , Economic Patriarchy $=.79$, Religious Patriarchy $=.80$, Child Entrepreneurship $=.59$ ). The gross product of the reliability index was .85 Alphas. These high reliability coefficients confirmed that these variables were internally consistent.

\subsection{Administration of the Instrument}

The researcher personally administered the instrument to the subjects. A letter was previously sent to the Head Teacher requesting permission to collect data from selected schools. The letter also explained the purpose of the study asking permission to administer research instrument on children.

\section{Method of Data Analysis}

Descriptive statistics of mean and standard deviation were used to answer research questions while inferential statistics of independent t-test statistics was used in hypotheses testing at .05 level of significance.

\subsection{Findings and Discussion}

Hypothesis 1: There is no significant influence of parental patriarchy on child entrepreneurship in Akwa Ibom North-East Senatorial District of Akwa Ibom State.

Table1. Summary of t-test of Significant Influence of Parental Patriarchy on Child Entrepreneurship in Akwa Ibom North East of Akwa Ibom State $n=1448$

\begin{tabular}{|l|l|l|l|l|l|}
\hline Dependent Variable & Independent Variables & $\mathbf{N}$ & Mean & Std. Dev. & Std. Error Mean \\
\hline Child Entrepreneurship & Female parental patriarchy & $56.34 * *$ & 8.86 & 1446 & .000 \\
\cline { 2 - 3 } & Male parental patriarchy & & & & \\
\hline
\end{tabular}

$* *$ Significant at $t(1446)=56.34, p<.05,2$-tailed .

Table 1, the result shows statistical significant, $\mathrm{t}(1446)=56.34, p<.05$, 2-tailed test. As presented in table 6, the result is significant because the computed t-value of 56.34 is greater than the $p$-value at .05 level of significance, 1446 degrees of freedom and two tailed test. Hence, the hypothesis that there is no significant influence of parental patriarchy on child entrepreneurship in primary schools in Akwa Ibom North-East Senatorial District of Akwa Ibom State is rejected.

Hypothesis 2: There is no significant influence of economic patriarchy on child entrepreneurship in Akwa Ibom North-East Senatorial District of Akwa Ibom State.

Table2. Summary of t-test of Significant Influence of Economic Patriarchy on Child Entrepreneurship in Akwa Ibom North-East Senatorial District of Akwa Ibom State $n=1448$

\begin{tabular}{|l|l|l|l|l|l|}
\hline Dependent Variable & Independent Variables & N & Mean & Std. Dev. & Std. Error Mean \\
\hline Child Entrepreneurship & Female economic Patriarchy & $82.11^{* *}$ & 9.44 & 1446 & .000 \\
\cline { 2 - 4 } & Male economic Patriarchy & & & & \\
\cline { 2 - 6 }
\end{tabular}

$* *$ Significant, $t(1446)=82.11, p<.05,2$-tailed .

Table 2, the result shows statistical significant, $\mathrm{t}(1446)=82.11, p<.05$, 2-tailed. As presented in table 4.8 , the result is significant because the computed t-value of 82.11 is greater than the $p$-value at .05 level of significance, 1446 degrees of freedom and two tailed test. Hence, the hypothesis that there is no significant influence of economic patriarchy on child entrepreneurship in primary schools in Akwa Ibom North-East Senatorial District is rejected.

Hypothesis 3: There is no significant influence of religious patriarchy on child entrepreneurship in Akwa Ibom North-East Senatorial District of Akwa Ibom State. 
Patriarchy and Child Entrepreneurship in Akwa Ibom North-East Senatorial District of Akwa Ibom State, Nigeria.

Table3. Summary of t-test of Significant Influence of Religious Patriarchy on Child Entrepreneurship in Primary Schools $n=1448$

\begin{tabular}{|l|l|l|l|l|l|}
\hline Dependent Variable & Independent Variables & $\mathbf{n}$ & Mean & Std. Dev. & Std. Error Mean \\
\hline Child Entrepreneurship & Female religious Patriarchy & $76.98^{* *}$ & 8.47 & 1446 & .000 \\
\cline { 2 - 4 } & Male religious Patriarchy & & & & \\
\cline { 2 - 3 }
\end{tabular}

$* *$ Significant, $t(1446)=76.98, p<.05,2$-tailed .

Table 3, the result shows statistical significant, $\mathrm{t}(1446)=76.98, p<.05,2$-tailed test. As presented in table 4.9, the result is significant because the computed t-value of 76.98 is greater than the $p$-value at .05 level of significance, 1446 degrees of freedom and two tailed test. Hence, the hypothesis that there is no significant influence of religious patriarchy on child entrepreneurship in primary schools in Akwa Ibom North-East Senatorial District is rejected.

\subsection{Discussion of Findings}

The finding of this study in hypothesis one indicates significant influence of parental patriarchy on child entrepreneurship in primary schools in Akwa Ibom North-East Senatorial District. The significant influence observed from the finding of this study indicated that child entrepreneurship is affected by the pattern of rearing style parents adopt. This finding is in support of the findings of Kambarami (2006), who found that Nigerian males are socialized to view themselves as breadwinners and heads of households whilst females are taught to be obedient and submissive housekeepers. The influence of parental patriarchy on child entrepreneurship is further supported by Effiong (2010), who established that a girl child is always provided with a hair-breaded babyish toy or kitchen utensils to play with whilst a boy child is provided toy cars, puzzle games and other toys that require physical energy or mental ability and this give opportunity for the boy to be independent.

The finding of this study in hypothesis two indicates significant influence of economic patriarchy on child entrepreneurship in primary schools in Akwa Ibom North-East Senatorial District. The result indicated that children who were in high economic patriarchy in their respective homes experience high influence on entrepreneurship than their counterparts who were in low economic patriarchy. This study is at variance with the finding of Kambarami (2006), who stated that most women occupy less challenging positions like secretarial or clerical positions and few in administrative positions. Though, there is a patriarchal experience, it is observed that women in the study area are not completely subjected to less challenging positions, some of them are managers of industries and firms. The finding of this study is in support of the finding of Udoh (2004) who revealed that skills development as part of entrepreneurship in most traditional industries were imparted through functionally and informal education that introduced gender disparity among trainees based on the gender role and identity as perceived by industrial leaders of the community.

The finding in hypothesis three of this study indicates significant influence of religious patriarchy on child entrepreneurship in primary schools in Akwa Ibom North-East Senatorial District of Akwa Ibom State. The result indicates that female children who were in high religious patriarchy in their respective homes experience high influence on entrepreneurship than their counterparts who were in low religious patriarchy. Hence, the high influence of religious patriarchal activities subjected them to subordinate position that similarly influences their entrepreneurship outside the religious environment. This personality disposition could allow these caliber of children to exercise their entrepreneurial skills in order to be managers of firms in future which, of course would expose them as leaders.

The result of this study is in congruence with the findings of Silverstein, Auerbach and Dunkel (2009), who revealed that men's roles are not patriarchal but one of spiritual leaders and that their position as leaders are both religiously and biologically sanctioned. Silverstein, Auerbach and Dunkel further stated that by redefining the father as spiritual leader rather than patriarch, the father maintains power and status. It is believed that religious leadership in ancient of times was always operated and monopolized by men due to the ancient biblical history. That is why some religions do not allow women to pray with men, while some religions accept women to pray with men but cannot lead in any aspect of their service. The religious patriarchy seems to be the root for patriarchal activities that influence the parental and economic entrepreneurship of the child in this study. 


\section{CONCLUSION}

Based on the findings of this study, patriarchy has been recognised as the primary source of regulating children's entrepreneurship positively or negative due to the influence it exerts on their social behaviours. The belief and practice of male dominance do not allow for gender sensitivity and equality in education religious settings, cooperate work place and political offices. This in no doubt is found to hinder the leadership and entrepreneurial skills and potentials of females, to enhance industrial technological and societal growth as well as self-reliance.

\section{RECOMMENDATIONS}

The following recommendations were made based on the findings of this study, that:

1. Parents should endeavour to reorganize their female children's rearing patters in order to cultivate equality beliefs in them to inhibit patriarchal reasoning that would pose a serious challenge in motivating them for the development of entrepreneurship skills.

2. Though the influence of economic patriarchy is not really much, parents should establish equality among their children in grooming female children's economic potentials to expose them to various rearing styles that could encourage and promote physical as well as cognitive strength in them to bolster female entrepreneurship. This would motivate the girl-child to learn skills that would possibly tend to promote their entrepreneurial development in the future.

3. Religious organizations such as churches, mosques among others should endeavor to allow girlchildren to participate in leadership activities to learn similar values like their male counterparts. These opportunities would help to remove fear and withdrawal behaviours since the same spiritual doggedness can be transformed to business spheres of their life as entrepreneurs.

\section{REFERENCES}

[1] Adichie, C. N. (2009). The Danger of a Single Story (lecture). Ibadan: NED-Press.

[2] Akuezuilo, D. and Agu, T. (2003). National Youth Entrepreneurship Policy in Ghana. A Paper Delivered during a Workshop Organized by the Institute of Continuing and Distance Education, University of Ghana.

[3] Baba, G. K. (2013). The Challenges of Entrepreneurship Development in Nigeria and Way Forward. Journal of Business and Organizational Development, 5(1):54 - 64.

[4] Bula, H. O. (2012). Evolution and Theories of Entrepreneurship: A Critical Review on the Keyan Perspective. International Journal of Business and Commerce, 1(11):81 - 96.

[5] Buss, D. M. and Schmitt, D. P. (2011). Evolutionary Psychology and Feminism. Sex Roles, 6(4):9 - 10.

[6] Ebom, J. M. (2015). Preserving the Landscape of Imagination: Children's Literature in Africa. Amsterdam: Rodopy Publishers.

[7] Effiong, S. C. (2010). School Activities and Language Development in Children. Unpublished M.Ed Seminar Paper, Graduate School, University of Calabar, Calabar, Nigeria.

[8] Effiong, S. C. (2012). Domestic Violence and Married Teachers Tasks' Performance in Secondary Schools in Akwa Ibom State. Unpublished M.Ed. Thesis, University of Calabar, Calabar, Nigeria.

[9] Effiong, S. C. (2015). The Life-Span Growth and Development of Adolescence: Discussion and Identification of Stages. Unpublished Ph.D Seminar Paper, University of Uyo, UYo, Nigeria.

[10] Emmanuel, C. L. (2008). Entrepreneurship: A Conceptual Approach. Lagos: Pumark Nigeria Limited.

[11] Ezenwa-Ohaeto, W. (2015). Fighting Patriarchy in Nigerian Cultures through Children's Literature. Journal Studies in Literature and Language, 10(6):59 - 66.

[12] Hooks, B. (2010). Ain't I a Woman? Black Women and Feminism. Boston: South End Press

[13] Johnson, A. G. (2005). Gender Knot: Unraveling our Patriarchal Legacy (Revised Edn.). Philadelphia: Temple University Press.

[14] Kambarami, M. (2006). Feminity, Sexuality and Culture: Patriarchy and Female Subordination in Zimbabwe. African Regional Sexuality Resource, 1, $1-8$.

[15] Makama, G. A. (2013). Patriarchal and Gender Inequality in Nigeria: The Way Forward. European Scientific Journal, 9(17):113 - 114.

[16] Obisong, O. N. (2005). Business Ownership in Nigeria. Calabar: University of Calabar Press.

[17] Oguejiofor, O. J. (2015). Power Gender Relations Character and Nation Building. A Lecture Delivered at the 2nd Colloquium of Prof Ezenwa-Ohaeto Seminar at Awka, Nigeria. 
Patriarchy and Child Entrepreneurship in Akwa Ibom North-East Senatorial District of Akwa Ibom State, Nigeria.

[18] Oteh, A. (2009). The Role of Entrepreneurship in Transforming the Nigerian Economy. The Seventh Convocation Lecture, Igbinedion University, Okada, Benin.

[19] Praag, C. M. V. and Versloot, P. H. (2007). What is the Value of Entrepreneurship? IZA Discussion Paper No. 3014. Available atftp.iza.org/dp3014pdf. Accessed on Friday, April 17, 2016.

[20] Silverstein, L. B., Auerbach, C. F. and Dunkel, G. F. (2009). Do Promise Keepers Dream of Feminist Sheep? Sex Roles Journal of Research, 665, 22 - 25.

[21] Sultana, A. (2011). Patriarchy and Women's Subordination: A Theoretical Analysis. The Arts Faculty Journal, 6, 1 - 18.

[22] Thornton, P. H. (2009). Sociology of Entrepreneurship, Annual Review of Sociology, 25:19 - 26.

[23] Tickner, A. J. (2011). Gender in World Politics. In: Baylis, J., Smith, S. and Owens, P. (Eds.), The Globalisation of World Politics: An Introduction to International Relations (5th Edition). Oxford: Oxford University Press, pp. $24-32$.

[24] Tuned, D. P. (2011). Patriarchy as Discourse: The Gendering of Art Education, 6(2):73 - 81.

[25] Udoh, J. S. (2004). Social Studies Education: Methodology and Concept. Uyo: Samuf Educational Publishing,

Citation: OBINAJU, Queen Idongesit (Ph.D), et.al. "Patriarchy and Child Entrepreneurship in Akwa Ibom North-East Senatorial District of Akwa Ibom State, Nigeria." International Journal of Humanities Social Sciences and Education (IJHSSE), vol 7, no. 2, 2020, pp. 6-13. doi: http://dx.doi.org/10.20431/2349-0381. 0702002.

Copyright: () 2020 Authors. This is an open-access article distributed under the terms of the Creative Commons Attribution License, which permits unrestricted use, distribution, and reproduction in any medium, provided the original author and source are credited. 